\title{
O ESPÍRITO PRESENTE EM MEIO ÀS AMBIGUIDADES DA VIDA: TRAÇOS DA PNEUMATOLOGIA SIMBÓLICA DE PAUL TILLICH
}

The Spirit Presented in the Ambiguities of Life: Traces of Paul Tillich' Symbolic Pneumatology

Pedro Rubens Ferreira Oliveira *

RESUMO: O presente artigo indica alguns traços da pneumatologia de Paul Tillich, a partir de um estudo da quarta parte de sua Teologia Sistemática, A Vida e o Espírito, na qual o autor aborda a correlação entre a questão da ambiguidade da vida e a resposta simbólica de uma teologia do Espírito. Num primeiro momento, traçam-se as bases antropológicas de uma pneumatologia. Em seguida, aborda-se a Presença do Espírito de Deus no espaço e no tempo, nas mediações históricas, dentro da dinâmica escatológica do já e do ainda não. Enfim, antes de concluir com os indicativos de um discernimento teológico necessário, reflete-se sobre a Presença Espiritual face ao paradoxo das Igrejas e ao apelo de uma abertura ao diálogo com outras religiões e outras formas de crer e de viver, onde o Espírito de Deus trabalha.

PALAVRAS-CHAVE: Pneumatologia. Ambiguidade da vida. Presença Espiritual. Discernimento teológico.

ABSTRACT: The following article indicates traces of the pneumatology of Paul Tillich according to the study of the fourth part of his Systematic Theology, Life and the Spirit, where the author approaches the correlation between the ambiguity of life and the symbolic response of a theology of the Spirit. Firstly, the anthropological foundations are set for a theology of the Spirit. Then, the Presence of the Spirit of God is approached regarding space and time, historical mediations,

*Universidade Católica de Pernambuco, Recife, Pernambuco, Brasil. 
and within the eschatological dynamic of already and not yet. Finally, before concluding with the indications of a necessary theological discernment, the Spiritual Presence is reflected upon the paradox of Churches and the appeal to open to dialogue with other religions and other ways of believing and living, where the Spirit of God works.

KEYWORDS: Pneumatology. Ambiguity of Life. Spiritual Presence. Theological Discernment.

\section{Introdução}

Segundo a tradição bíblica e espiritual, a presença divina está nos seres Svivos, em toda a criação ${ }^{1}$. Mas, ao mesmo tempo, a vida revela ambiguidades de toda sorte. A experiência da fé não escapa a essa realidade, entretanto, ela inscreve-se em uma dinâmica de superação. Ora, a situação da fé no Brasil está predominantemente marcada por uma ambiguidade multiforme e por uma efervescência religiosa sem precedentes. Por isso, faz-se necessário, na teologia, passar de um juízo a priori das experiências religiosas a um discernimento dos sinais de Deus nos acontecimentos, exigências e aspirações de nosso tempo (Gaudium et Spes, 11), segundo o princípio conciliar da pastoralidade (THEOBALD, 2007; 2012).

Nesse cenário, importa revisitar Paul Tillich, um pensador de fronteiras "a fronteira é o melhor lugar para pensar" (TILLICH, 2002, p. 13) - que elaborou sua teologia em "constante diálogo e confronto com os movimentos sociais, políticos, filosóficos, científicos e artísticos do século XX" (HIGUET, 2019 , p. 13) ${ }^{2}$. Certamente o contexto do teólogo alemão que migrou para os Estados Unidos no século passado é bem diferente de nossa situação. Entretanto, Tillich é um interlocutor apropriado para pensar a ambiguidade religiosa brasileira: primeiro, porque ele, diferentemente da maioria dos teólogos do século $X X$, não faz uma oposição radical entre fé e religião ${ }^{3}$, sob pretexto de purificar a fé da ambiguidade religiosa, tão criticada pela modernidade. Ele constata que a fé e a religião são ambíguas, porque a vida é ambígua, deslocando assim a questão para uma antropologia fundamental. Em segundo lugar, seu método da correlação propõe um diálogo com

\footnotetext{
1 "Olhar como Deus habita nas criaturas: nos elementos, dando o ser; nas plantas, a vida vegetativa; nos animais, a vida sensitiva; nas pessoas, a vida intelectiva. Do mesmo modo em mim, dando o ser, o viver, o sentir e o entender" (LOYOLA, 2000, p. 92-93, n. 235).

${ }^{2}$ Sobre a atualidade da teologia de Paul Tillich e a pertinência de sua interlocução para pensarmos a realidade brasileira, ver Higuet (2019, p.11-25): no presente artigo, em suas primeiras versões, o autor retrata a realidade do final do século passado, mas, de certa forma, o desafio teológico não mudou, apenas está mais agudo: trata-se de buscar uma terceira via para evitar, por um lado, o fundamentalismo e, por outro, a perda da identidade cristã. ${ }^{3}$ Para melhor compreender a relação e diferença entre os conceitos tillichianos de fé e religião, ver os dois artigos de Gross (2013a, p. 7-26; 2013b, p. 59-76).
} 
a cultura e suas mediações, exercitando uma abordagem multidisciplinar, indispensável para compreender o ato de fé em sua complexidade ${ }^{4}$. Enfim, na sistematização de sua teologia ${ }^{5}$, ele buscou correlacionar as grandes questões da existência com as respostas simbólicas da fé cristã. Face ao problema da ambiguidade humana, Tillich propõe reinterpretar um dos símbolos da fé: Deus como Espírito.

Apresentaremos, neste artigo, alguns traços da pneumatologia tillichiana, expressos na quarta parte de sua Teologia Sistemática ${ }^{6}$, A Vida e o Espírito, na qual ele aborda a correlação entre a ambiguidade humana radical e o Espírito divino. Num primeiro momento, veremos as bases antropológicas de uma teologia do Espírito. Em seguida, abordaremos a Presença do Espírito de Deus no espaço e no tempo, dentro da dinâmica escatológica do já e do ainda não. Enfim, antes de concluir com os indicativos de um discernimento teológico, refletiremos sobre a Presença Espiritual face ao paradoxo das Igrejas e ao apelo de uma abertura ao diálogo com outras religiões e outras formas de crer e de viver, nas quais o Espírito de Deus, incessantemente, trabalha.

\section{Espírito de Deus e ambiguidade humana}

A definição tillichiana de símbolo religioso pressupõe a teoria do realismo simbólico ${ }^{7}$ o símbolo não é uma forma vazia, mas um movimento dinâmico que remete a algo para além de si mesmo, embora participando daquilo ao qual remete. De fato, Deus como ser-em-si constitui a forma da sua Teologia Sistemática, mas é a noção de símbolo que dá a dinâmica de seu pensamento (EMÍLIO, 2010, p. 157). O símbolo é, segundo Tillich, a linguagem da religião, e a dimensão religiosa não é apenas uma função

\footnotetext{
${ }^{4}$ Por que recorrer ainda hoje ao método tillichiano? Ver nossa contribuição: RUBENS, P. La foi aux prises avec l'ambiguïté postmoderne: Penser avec Paul Tillich la méthode théologique. In: DANZ, C. et al. (Ed.). International Yearbook for Tillich Research. Berlin; Boston: De Gruyter, 2016. p. 1-22.

${ }^{5}$ Não encontrei melhor definição da visão tillichiana de sistema: “Elabora-se um sistema quando se quer fazer aparecer as correspondências, as articulações, as interações dinâmicas que sustentam a experiência e o saber. Trata-se de explicitar as relações que existem entre as sensações, as ideias e os fatos, e não, como alguns temem, de estabelecer uma ordem dedutiva do tipo matemática onde as proposições 'não fundadas sobre a experiência' se encaixam rigorosamente segundo as regras formais e abstratas. O sistema não impõe um quadro artificial, ele visa trazer à luz o funcionamento da experiência e a organização interna do real" (GOUNELLE, 2013, p. 27, tradução nossa).

${ }^{6}$ A Teologia Sistemática (TS), obra da maturidade de Tillich, é composta de cinco partes, sempre relacionando dois termos: 1. A Razão e a Revelação; 2. O Ser e Deus; 3. A Existência e Cristo; 4. A Vida e o Espírito; 5. A História e o Reino de Deus. Ver a apresentação feita pelo próprio autor (TILLICH, 1984, p. 13-64).

${ }^{7}$ Sobre os fundamentos da teoria dos símbolos de Paul Tillich, ver Abreu (2019, p. 1-36).
} 
especial da vida (espiritual), mas o fundamento de todas as funções humanas (ABREU, 2019, p. 7). O símbolo cristão do Espírito nos remete à santidade e dela participa: Deus como Espírito é dado à experiência como aquele que é o único Santo. Mas como compreender a relação entre Deus como Espírito, em toda sua transcendência, e o espírito humano, em sua finitude e liberdade incontornáveis?

\subsection{O Espírito, símbolo de Deus}

Para falar de Deus como Espírito, Tillich resgata o termo espírito (com um " $\mathrm{e}$ " minúsculo) para designar o ser humano integralmente e, assim, falar analogicamente de Deus (TILLICH, 1991, v. 4, p. 23-29). Nesse sentido, uma teologia do Espírito não é possível sem o conhecimento do espírito humano (TILLICH, 1991, v. 4, p. 124). A ambiguidade manifesta-se em todas as criaturas, mas só se torna experiência e reflexão no ser humano, porque ele é portador do Espírito.

O simbolismo religioso produziu, segundo Tillich, três grandes conceitos de superação da ambiguidade da vida: o Espírito de Deus, o Reino de Deus e a Vida eterna ${ }^{8}$. Privilegiaremos aqui o primeiro símbolo porque ele está "diretamente em correlação com as ambiguidades da vida" e porque a descrição paulina do Espírito diz respeito à fé e à realização humana (TILLICH, 1968, p. 85-87). A realização do ser humano inscreve-se, portanto, em três dinamismos: a experiência de integração (e integridade porque ele a associa à moralidade); a experiência cultural (ou criatividade) e a experiência da transcendência (fé e religião).

Pensar o Espírito como símbolo de Deus pressupõe duas perspectivas de pesquisa: a analogia para dizer Deus e a linguagem simbólica como a única capaz de exprimir o (sentido) último e decisivo de nossa existência. Tillich chama de analogia imaginis o encontro dessas duas perspectivas. Ora, o símbolo permite não só dizer, mas também pensar Deus como Espírito. O Espírito como símbolo permite pensar Deus não como um ser distinto e distante do ser humano, mas como Deus presente a/em nós: $\mathrm{O}$ "Espírito de Deus é a presença da vida divina no interior da vida da criatura" (TILLICH, 1991, v. 4, p. 120). Por isso, ele prefere falar de Presença Espiritual (PE): a palavra presença tem uma conotação arcaica que designa o lugar onde está um soberano ou um grupo de altos dignitários; escrevendo com maiúsculas, Tillich quer exprimir a Presença divina na vida da criatura (TILLICH, 1991, v. 4, p. 120). Mas resta saber como essa PE se manifesta.

\footnotetext{
${ }^{8}$ Nas cinco partes da TS, o Espírito de Deus é tratado na quarta parte, enquanto o Reino de Deus e a Vida eterna na $5^{\underline{a}}$ parte (TILLICH, 1963, v. 3). Na edição brasileira, os três volumes foram unificados e são tratados na última parte da obra (TILLICH, 1984, p. 387-610).
} 


\subsection{A manifestação da Presença Espiritual no espírito humano}

A tradição cristã tematizou a relação entre o espírito humano e o Espírito de Deus com metáforas, entre elas: o Espírito permanece e opera (works) no espírito. Poderia, porém, o Espírito divino permanecer e operar no espírito humano sem provocar sua despersonalização ou sem tornar imanente a transcendência divina?

Que o Espírito divino sobrevenha (breaks into) no espírito humano, isso não significa que resida nele, mas que o move (drives) a sair de si mesmo (TILLICH, 1963, v. 3). Isso quer dizer que a função do Espírito consiste em um movimento dinâmico de transcendência do espírito humano: não para buscar a última (derradeira) possibilidade, mas aquilo que é último (decisivo). Daí a noção tillichiana de êxtase: embora permanecendo o que ele é, por um movimento extático, o ser humano é conduzido a sair de si mesmo, sob impulso da PE (TILLICH, 1984, p. 470-471). O caráter extático da PE não entra em concorrência com o espírito humano: o Pneuma opera na humanidade na perspectiva de realizar aquilo que o espírito humano sozinho não pode fazer, isto é, superar a ambiguidade.

Enfim, o ser humano transcende a si mesmo mediante um movimento de ek-stasis: uma saída de si suscitada pela PE em vista de sua realização integral. Esse movimento extático, enquanto saída de si mesmo em direção ao sentido último, expressa-se em duas perspectivas diferentes: uma chama-se fé, e a outra, amor; pela fé, faz-se a experiência de ser agarrado (HIGUET, 2019, p. 14) por Deus e, pelo amor, se adere a Ele.

\subsection{A manifestação da Presença Espiritual como fé}

Se a fé consiste em ser orientado por uma preocupação com o sentido último - ultimate concern ${ }^{9}$ - da existência (TILLICH, 1991, v. 4, p. 144), sob o regime do Espírito, ela é o "estado de ser possuído pela PE e aberto à unidade transcendente da vida sem ambiguidade" (TILLICH, 1984, p. 485). Ora, o que se diz em relação ao Espírito encontra sua analogia em relação a Cristo, deve-se dizer relativamente à afirmação cristológica que a fé é o estado em que se é totalmente tomado (o autor diz possuído) pelo Novo Ser manifestado em Jesus como Cristo. Tillich sublinha aqui uma passagem: segundo essa definição, o conceito formal e universal da fé (sentido amplo) torna-se material e particular, isto é, cristão (TILLICH, 1984, p. 485).

\footnotetext{
${ }^{9}$ A expressão ultimate concern é difícil de traduzir em português: refere-se à preocupação com o que é mais decisivo para a existência humana, que Tillich gosta de chamar de último que importa, aqui traduzido por Sentido Último. Em todo caso, essa noção ampla de religião permitirá pensar um diálogo com a cultura e realizar um movimento de abertura do cristianismo ao encontro de outras religiões. Ver Tillich (2015) e Ribeiro e Abijaudi (2017).
} 
O Espírito como símbolo de Deus participa e remete à santidade, experiência cristã que vai além das fronteiras do cristianismo: o Espírito de Deus está presente e opera a "realização do ser humano em toda sua humanidade" (RUBENS, 2004, p. 434s, tradução nossa). Tillich retoma duas conclusões de seu estudo sobre a fé, aplicando-as ao símbolo do Espírito. Primeiramente, nenhum procedimento isolado da inteligência, nenhum esforço da vontade, nenhum movimento da afetividade pode produzir ou gerar a fé (TILLICH, 1968, p. 47-56). A fé integra tudo isso para uni-lo e submetê-lo ao poder dinâmico de transformação da Presença do Espírito. Confirma-se assim, diz o autor, uma verdade teológica fundamental segundo a qual "na relação com Deus, tudo vem de Deus" (TILLICH, 1984, p. 487). O espírito humano não pode, por si só, alcançar o sentido último, mas, pela dinâmica da fé, este último pode elevar suas capacidades acima delas mesmas.

O conceito material de fé corresponde, enfim, a três aspectos principais: a abertura pela PE (o aspecto receptivo da fé); a aceitação dessa abertura pelo ser humano, a despeito do fosso que separa o Espírito divino do espírito humano (o aspecto paradoxal da fé); a esperança de participação final à união transcendente da vida-sem-ambiguidade (a fé como antecipação, esperança do cumprimento do Espírito criador). Esses três elementos exprimem a situação humana e da vida em geral em relação ao que é Último e definitivo. Correspondem às características do Novo Ser, Jesus como Cristo (TILLICH, 1970, v. 2, p. 208-212), enquanto Ele é potência de salvação, manifestada como regeneração, justificação e santificação: isso diz respeito à superação da ambiguidade pela PE (TILLICH, 1984, p. 487).

\subsection{A manifestação da Presença Espiritual como amor}

Pressupondo o aprofundamento em sua outra obra - Amor, poder e justi$c_{c} a^{10}$ - nosso autor contenta-se aqui (TILLICH, 1964, p. 16-25) em situar o tema do amor no seu sistema, afirmando que o amor se torna efetivo em todas as funções do espírito e que se enraíza no mais profundo da vida (1991, p. 148). O termo amor tem muitas significações ${ }^{11}$ : philia (amizade), eros (aspiração ao valor), epithymia (desejo) e ágape (amor criado pelo Espírito, segundo a compreensão cristã) (TILLICH, 1991, v. 4, p. 15). No Novo Testamento (NT), ágape designa "o amor criado pelo Espírito de Deus" e o autor traduz como sendo o "desejo de reunir o que está separado", movimento que constitui a dinâmica interna da vida (TILLICH, 1991, v. 4, p. 148). Como Tillich observou em relação à fé, o amor assim caracterizado torna-se impossível se não for suscitado pelo Último, mediante a experiência de êxtase (saída de si) do espírito humano: a fé é a saída de si

\footnotetext{
${ }^{10}$ Cf. TILLICH, 1964, edição original de 1960.

${ }^{11}$ Partindo da constatação, na época atual, de um desgaste e saturação da palavra amor, José Tolentino Mendonça faz uma reflexão sobre a insistência bíblica na pluralidade de acessos e propõe uma "teologia da amizade" (MENDONÇA, 2013, p. 15), evocando essas muitas significações do termo amor.
} 
suscitada pela PE; esta põe em questão a tendência de todo espírito finito de acomodar-se em sua autossuficiência.

Tal compreensão da fé e do amor implica desafios importantes para o diálogo entre a teologia católica e a protestante: nessa interpretação, identifica-se a concepção luterana da fé como ato unicamente receptivo e, ao mesmo tempo, reafirma-se a tese católica-agostiniana, segundo a qual fé e amor são inseparáveis. Nesse sentido, o amor é mais do que uma simples consequência da fé: amor e fé são duas manifestações da PE no ser humano, impelindo-o a buscar a realização de sua própria humanidade (TILLICH, 1991, v. 4, p. 149).

Diante da ameaça de deformação, o autor recorda o "princípio protestante" como um dispositivo crítico eficaz: na relação para com Deus, tudo vem de Deus (TILLICH, 1984, p. 487). Mas ele acrescenta que existe algo no ser humano que permite reconhecer a Deus como Deus. Isso possibilita a fé e o amor, como experiências do Espírito: “Ser tomado por Deus na fé e aderir a Ele no amor são, na vida da criatura, um só e o mesmo estágio, o da participação à união transcendente da vida-sem-ambiguidades" (TILLICH, 1991, v. 4, p. 153, tradução nossa).

\section{A Presença do Espírito na dinâmica escatológica}

A resposta teológica tillichiana à ambiguidade antropológica radical situa-se na dinâmica escatológica de uma Presença do Espírito de Deus na história, embora não em Sua plenitude; ele não se identifica com o chrónos, mas suscita os kairoi (momentos privilegiados) da história. E a PE não se manifesta de maneira abstrata, mas na humanidade concreta; não na história em geral, mas na singularidade da história das pessoas e grupos (TILLICH, 1991, v. 4, p. 153). Quando falamos da PE, do Novo Ser ou do ágape, designamos o que não está dentro de uma dinâmica de superação da ambiguidade (TILLICH, 1991, v. 4, p. 155).

\subsection{Experiência fragmentária, mas sem ambiguidade}

Por trás da noção tillichiana de ambiguidade, há uma mistura de elementos essenciais e existenciais, resultado da divisão sujeito/objeto (que dá o caráter positivo da ambiguidade), uma necessidade de buscar o significado da vida no meio do condicionado, um caráter ambivalente de todas as realizações humanas e uma incapacidade de alcançar o sentido último da existência (CRUZ, 2008, p. 141). Sua noção de ambivalência ${ }^{12}$ ou ambiguidade é rica

${ }^{12}$ Eduardo Cruz (2008) prefere falar mais de ambivalência, certamente por conta de sua busca de diálogo com as ciências exatas, enquanto nós trabalhamos mais com a noção de ambiguidade. 
e cheia de matizes, mas importa recordar uma distinção fundamental entre ambiguidade e fragmentariedade, tema importante sobretudo com a consciência contemporânea da fragmentação (ADÃO, 2019) ${ }^{13}$.

Segundo Tillich, o conceito de fragmento difere totalmente do de ambiguidade: uma realidade que não é submetida à ambiguidade manifesta-se nos limites da finitude, portanto de uma maneira fragmentária, em razão das condições espaço-temporais próprias da finitude humana (TILLICH, 1991, v. 4, p. 165s). Neste sentido, as experiências da PE, do Novo Ser, ou do Amor (ágape), são consideradas não propriamente como ambíguas, mas fragmentárias. Na medida em que essas três experiências são mediações da Presença divina, elas não estão condicionadas à ambiguidade. Com efeito, a noção de fragmentário permite a Tillich sustentar sua tese da ambiguidade humana radical e, ao mesmo tempo, afirmar a irrupção do Último no seio dessa situação: o Último está presente na experiência humana, embora de forma fragmentária (TILLICH, 1991, v. 4, p. 155).

Depois dessa descrição da Presença do Espírito divino no espírito humano, Tillich precisa o lugar dessa manifestação na humanidade histórica do Novo Ser. O acontecimento da Revelação representa um kairós, um momento privilegiado. Mas, enquanto a cristologia pode referir-se a um momento histórico determinado, a manifestação do Espírito é diferente: a pneumatologia pressupõe uma continuidade do Espírito ao longo de toda a história passada e futura. Na proposta tillichiana, no entanto, a ênfase é dada aos lugares de manifestação do Espírito como Presença. Tillich apresenta três lugares fundamentais da PE: nas outras religiões, em Jesus Cristo e na Comunidade Espiritual.

\subsection{O Espírito de Deus e a ambiguidade das religiões}

A PE e a antecipação do Novo Ser nas religiões: "com esse título poder-se-ia escrever uma história completa das religiões, porque nos oferece uma chave de leitura que permite descobrir um sentido no caos aparente da experiência religiosa vital da humanidade" (TILLICH, 1991, v. 4, p. 155, tradução nossa). A respeito de como tal programa ultrapassaria os limites de uma teologia sistemática, Tillich apenas menciona algumas manifestações típicas da PE (TILLICH, 1991, v. 4, p. 156-157).

Segundo o princípio protestante, deve-se conservar uma atitude crítica em relação a todo conhecimento objetivo do Último. Apesar dessa reserva, Tillich não desiste de procurar estruturas comuns entre os diversos caminhos de busca do Último, presentes nas diversas expressões religiosas

\footnotetext{
${ }^{13}$ Importa discernir nossa forma de viver a fragmentação, tão presente na mentalidade contemporânea e tratada, recentemente, na tese do jovem teólogo Francys Adão, defendida nas Facultés Jésuites de Paris e em processo de publicação. Ver Adão (2019).
} 
e culturais (TILLICH, 2015) ${ }^{14}$. Nessa perspectiva, ele cultiva uma atitude de respeito para com outras tradições religiosas e culturais sem, contudo, renunciar à possibilidade de uma comunicação profunda e de verdadeiro encontro com Deus na fé.

Tillich arrisca mencionar dois lugares mais importantes da PE: primeiro, o misticismo asiático e europeu; segundo, o monoteísmo exclusivo do judaísmo e das religiões baseadas nele. Inicialmente, ele inscreve as outras religiões no seio das manifestações da PE como antecipação do Novo Ser. Entretanto, o caráter dessa antecipação não é da ordem do tempo da Revelação: Tillich não fala das outras religiões como prefigurações da Revelação cristã (GEFFRÉ, 1999, p. 201-213), mas como figuras da PE. Mas como o nosso autor estabelece a relação entre Jesus Cristo e o Espírito, entre cristologia e pneumatologia?

\subsection{Cristologia pneumatológica}

“O Espírito divino estava presente em Jesus como Cristo sem nenhuma distorção. Nele o Novo Ser surgiu como o critério de toda experiência espiritual, passada e futura" (TILLICH, 1991, v. 4, p. 156, tradução nossa). Com essa afirmação, Tillich parece dissipar toda sombra de heterodoxia cristã. Por sua vez, será que ele não acaba diminuindo a desejada abertura aos outros? Afinal, como o autor pode afirmar que o Novo Ser é "o" critério de toda a experiência passada e futura, e, ao mesmo tempo, sustentar que outras expressões religiosas e culturais podem ser manifestações da Presença do Espírito?

As afirmações cristológicas elaboradas na terceira parte de sua TS, "A Existência e o Cristo" (TILLICH, 1984, p. 245-383), não são colocadas em questão, mas o autor sente a necessidade de completá-las no marco de sua teologia do Espírito (TILLICH, 1991, v. 4, p. 159). Isso significa reler sua cristologia a partir do trabalho do Espírito "na (in) pessoa de Jesus como Cristo", o que denomina "cristologia pneumatológica" (TILLICH, 1984, p. 495s). Em Jesus, o espírito humano, embora submetido às condições individuais e sociais, estava totalmente habitado pela Presença divina: “Deus estava nele" (TILLICH, 1984, p. 495). E, em razão disso, Jesus foi reconhecido como o Cristo e como a incorporação decisiva do Novo Ser para a humanidade na história ${ }^{15}$. O teólogo alemão constata

${ }^{14}$ Essa obra recolhe uma série de conferências e de escritos de Tillich, entre 1957 e 1965, na qual o autor levanta tanto a questão do diálogo inter-religioso como o confronto do cristianismo com as grandes ideologias seculares (nacionalismos, socialismo e liberalismo). Além do valor dos textos para os pesquisadores, merece destaque a importante introdução de Jean Richard (TILLICH, 2015, p. 9-115).

${ }^{15} \mathrm{O}$ autor, em sua versão original, utiliza o termo embodiment e não o de Encarnação, como se encontra na tradução francesa (TILLICH, 1980, v. 3, p. 141). Preferimos falar de incorporação para o distinguir do campo tipicamente dogmático, sobretudo porque Tillich defende, nesta passagem, que a Encarnação é a incorporação decisiva, mas não é a única. 
que "os relatos sinóticos mostram que a tradição cristã dos primórdios estava determinada por uma cristologia pneumatológica" (TILLICH, 1984, p. 495). Menciona brevemente algumas passagens (o batismo de Jesus, as tentações no deserto, as curas, os exorcismos e a transfiguração) e levanta a questão de como o Espírito pôde estar tão inteiramente presente em uma humanidade histórica e singular. Para ele, a resposta encontra-se na narrativa da concepção de Jesus pelo Espírito (TILLICH, 1984, p. 496). Se esses poucos traços não bastam para fundar uma cristologia ou pneumatologia, indicam, contudo, as articulações possíveis e as considerações sobre as manifestações da PE, a saber: a fé e o amor. Mas como compreender a fé e o amor de Jesus, o Cristo?

Segundo Tillich (1984, p. 496-497), pode-se falar mais facilmente do amor de Cristo, segundo a mensagem evangélica, como um amor que foi até o extremo. Contudo, parece mais difícil falar da fé de Cristo. Segundo a tradição, Jesus, confessado como o Cristo, vivia em comunicação permanente com Deus, seu Pai. A cristologia do Logos e seus pressupostos na teologia de Paulo reforçaram essa tendência. Tillich considera (1984, p. 496), por fim, que as análises existencialistas da fé, incluindo o risco e a dúvida, não podem ser aplicadas a Jesus Cristo. Será que isso não implicaria, por sua vez, um cripto-monofisismo, ou seja, Cristo seria despojado de sua humanidade real?

O autor constata que esse risco existe até no protestantismo: apesar da importância dada pelos reformadores ao Cristo humilde e ao servo sofredor, a significação da fé é definida pela "justificação pela graça por meio da fé", que inclui o paradoxo do perdão dos pecados. Ora, compreendida nesse sentido, "não se pode aplicar a Cristo o paradoxo da fé, porque Cristo mesmo é o paradoxo" (TILLICH, 1984, p. 496). Mas, se a fé for entendida como o fato de ser tomado pela PE e, através dela, pela união transcendente da vida-não-ambígua, então deve-se dizer que a fé de Cristo é um estado de ser inteiramente habitado por essa Presença, livre de toda ambiguidade (TILLICH, 1991, v. 4, p. 160-161).

Retemos três das implicações principais da releitura pneumatológica da cristologia tillichiana. A primeira e fundamental é a distinção entre ambíguo e fragmentário, o que torna compreensível a fé de Cristo: as narrativas evangélicas testemunham a fé de Cristo em seu caráter fragmentário, com elementos de combate, esgotamento e desesperação. Contudo, esses elementos nunca levam à profanização de sua fé, porque o Espírito de Deus está sempre com ele. Em segundo lugar, não é o espírito de Jesus de Nazaré que faz dele o Cristo, mas a Presença de Deus nele: evita-se assim cair em uma Jesuologia, risco presente na teologia pietista e na teologia liberal; ambas entram em contradição com a cristologia paulina, a qual sublinha que o Senhor é Espírito. Uma terceira implicação de uma cristologia pneumatológica consiste em conceber Jesus, o Cristo, como chave de interpretação 
de todas as manifestações do Espírito na história. O acontecimento Jesus como Cristo é único, mas não é um acontecimento isolado e descontínuo: o Espírito que gerou o Cristo em Jesus é o mesmo Espírito que preparou e continua a preparar a humanidade para o encontro do Novo Ser n'Ele (TILLICH, 1991, v. 4, p. 162-163). A visão joanina do novo Paráclito, como aquele que nos conduzirá à plenitude da verdade, está aqui subjacente (TILLICH, 1984, p. 499). Segundo João, de fato, a relação entre Cristo e o Espírito manifesta-se em sua unidade e diferença: se o Espírito é o outro defensor, é porque Jesus também é defensor, sinal da unidade da missão do Filho e do Espírito; mas, se o Filho volta para o Pai, Jesus não os deixa órfãos (Jo 14,18), porque o Espírito permanecerá com os discípulos para sempre (MALZONI, 2018, p. 246).

\subsection{A Presença do Espírito na comunidade}

A comunidade ocupa, para Tillich (1991, p. 164), um lugar fundamental na acolhida do Novo Ser e da manifestação da Presença do Espírito nele: "Cristo não seria Cristo sem aqueles que o recebem enquanto Cristo, e Ele não teria podido instaurar uma realidade nova sem aqueles que a acolhem como sendo d'Ele e n'Ele". O autor prefere chamar de Comunidade Espiritual (CE) ao invés de Igreja, porque este termo ficou estreitamente ligado às ambiguidades da religião (TILLICH, 1991, v. 4, p. 164). A CE é, pois, a comunidade criada pelo Novo Ser (Jesus, o Cristo) sob o impulso do Espírito. E é precisamente do seu caráter espiritual implícito que deriva a relação dialética da $\mathrm{CE}$ com as Igrejas, análoga à relação entre o Cristo e Jesus e à relação entre a Revelação e a história das religiões. Nesses casos, só os olhos da fé podem ver o que está oculto, o que é espiritual e "só o Espírito pode discernir o Espírito" (TILLICH, 1991, v. 4, p. 264, tradução nossa).

Tillich destaca, na narração de Pentecostes, os sinais que permitem um discernimento das criações do Espírito e releva cinco elementos estruturantes da CE: primeiro, o caráter extático e dinâmico da experiência que, embora respeitando a estrutura do real e do humano, impele a ir além. Segundo a certeza que supera a dúvida: é a experiência da fé que foi ameaçada e quase destruída pela crucifixão do Novo Ser. Terceiro, a manifestação de um amor que se explicita no serviço mútuo, em particular em relação aos que estão à margem. Quarto, a Presença Espiritual cria a unidade, reunindo os indivíduos, de nacionalidades e tradições diferentes, em um movimento inverso à experiência da Torre de Babel. Enfim, o quinto elemento é a universalidade expressa pelo zelo missionário daqueles que foram tomados pela PE: trata-se aqui de uma expressão da abertura a todos, sem acepção de pessoas (TILLICH, 1984, p. 500-501).

Para Tillich (1984, p. 501), essas cinco características da narração de Pentecostes apontam para o fato de que "o Espírito divino é o Espírito de Jesus 
como o Cristo" e que "o Cristo é o critério ao qual toda reinvindicação Espiritual deve ser submetida". Contudo, a Comunidade do Novo Ser como obra do Espírito ultrapassa o círculo das Igrejas cristãs. Daí surge uma nova questão: que relação a CE mantém com as Igrejas históricas e outras formas de comunidades?

\subsection{Comunidade Espiritual "latente" e "manifesta"}

A distinção tillichiana de estágio latente e estado manifesto da Comunidade Espiritual ajuda a entender melhor o lugar das outras comunidades. Não se pode comparar esses dois estágios à distinção clássica entre Igreja visível e invisível, porque tais qualidades, segundo o autor, caracterizam a Igreja tanto em sua latência como em sua manifestação (TILLICH, 1984, p. 502). O que marca a passagem de um estágio ao outro, portanto, é o encontro com o Novo Ser manifestado em Jesus Cristo. Esse encontro, porém, não se refere propriamente ao acontecimento histórico que marcou nossa era, o kairós cristão fundamental. A delimitação de um antes e de um depois diz respeito aos kairoi derivados e recorrentes do encontro existencial de pessoas e de grupos religiosos e culturais com Jesus como Cristo. Na perspectiva do Espírito, tanto os hebreus de outrora como os humanistas contemporâneos estão em estado de latência da CE. Assim, movimentos de juventude, círculos de amigos, grupos educativos, artísticos e políticos que não pertencem a qualquer Igreja, podem até ser hostis para com todas as formas de expressão religiosa, não estão, necessariamente, excluídos da CE (TILLICH, 1991, v. 4, p. 168-169).

O conceito de Comunidade latente permite a Tillich reconhecer traços da PE em vários lugares e grupos (TILLICH, 1991, v. 4, p. 169-170). Esse reconhecimento amplo é possível por conta de seu conceito formal e amplo de fé e amor. Em todas essas situações, a CE fica latente, enquanto as pessoas não são confrontadas com o critério último e decisivo da fé e do amor de Jesus Cristo, representado, "real e simbolicamente", na Cruz (TILLICH, 1991, v. 4, p. 170). O autor considera que esses grupos estão, porém, em relação teleológica com as manifestações da CE e são orientados inconscientemente para Cristo, embora rejeitem a pregação e as ações das Igrejas cristãs. Assim, "eles podem se tornar críticos das igrejas em nome da $\mathrm{CE}$, e isso vale também para os movimentos anti-religiosos e anti-cristãos como o comunismo mundial" (TILLICH, 1984, p. 503).

Percebe-se, enfim, o cuidado de Tillich em conservar o universalismo crístico e fazer um esforço conceitual para não excluir os outros "daquilo a que a mensagem cristã se refere" ou seja aquilo que é decisivo para a realização humana plena. Nosso autor, homem de seu tempo, testemunha não apenas debates da época, mas aponta para uma "abertura audaciosa e equilibrada" na linha de um "ecumenismo inter-religioso" (GEFFRÉ, 2010, p. 106). 


\section{O Espírito de Deus face à ambiguidade da religião}

O trabalho do Espírito implica, segundo Tillich, as três funções da vida no domínio do espírito humano: a função do religioso, do cultural e da moral. Em sua Teologia Sistemática (TILLICH, 1991), ele trata da relação da CE com essas três funções, mas, segundo o recorte deste artigo, a nossa reflexão tratará unicamente da relação com a ambiguidade da religião.

\subsection{O paradoxo das Igrejas}

As Igrejas constituem a CE, manifestada enquanto confessam Jesus como Cristo. Tillich sublinha, no entanto, que a CE não existe como uma entidade à parte, ao lado das Igrejas, pois o dinamismo do Espírito constitui as Igrejas e suscita nelas a luta contra as ambiguidades da religião (TILLICH, 1991, v. 4, p. 181-182). Há, no entanto, dois aspectos na realidade dessas Igrejas que as tornam paradoxais: o aspecto sociológico, que evidencia suas ambiguidades, e o aspecto teológico, que indica sua dinâmica espiritual.

Enquanto realidade sociológica, a Igreja está submetida às leis que determinam a vida dos grupos sociais e, por isso, ela torna-se objeto de pesquisa das ciências sociais. Mas se o papel e a significação social das Igrejas são relevantes, não se deve entendê-las somente a partir desse aspecto: "uma Igreja que não é nada mais do que uma associação beneficente ou um grupo de utilidade social, podendo, em princípio, ser substituída por outros grupos que não pretendem ser Igrejas: a existência de Igrejas desse gênero não se justifica" (TILLICH, 1991, v. 4, p. 182-184, tradução nossa). A Igreja é uma realidade teológica e, deste ponto de vista, a presença da $\mathrm{CE}$ insere-se na sua própria dimensão sociológica.

No entanto, diz Tillich (1984, p. 512), o que ameaça e deforma o rosto da Igreja, tanto do ponto de vista sociológico como teológico, é a exclusividade. A Igreja não pode pretender compreender-se exclusivamente como realidade teológica, da mesma forma que nenhuma análise sociológica, apesar de sua importância, poderá abarcar toda a significação da Igreja (TILLICH, 1984, p. 512). E o teólogo luterano toma como exemplo uma posição tradicional da Igreja Católica Romana (TILLICH, 1984, p. 512s), na medida em que ela tenta ignorar as ambiguidades e apropria-se dos atributos da CE: a santidade, a unidade e a universalidade.

As Igrejas são santas por causa do Novo Ser presente nelas e os seus membros são santificados na medida em que querem pertencer à Igreja, porque recebem dela o que ela própria recebeu. A Igreja é santa por ser a comunidade dos que foram justificados pela graça por meio da fé. Chega-se assim ao ponto que parece intransponível para Tillich entre protestantismo e catolicismo: o primeiro não aceita que o predicado de santidade seja conferido às Igrejas, caso ele repouse em alguma forma institucional, 
como pretende o segundo. Interessante como o autor faz alusão ao Concílio Vaticano II como um momento em que a Igreja romana fez reviver nela "o princípio da reforma" (TILLICH, 1984, p. 513).

A unidade, segundo atributo das Igrejas, só pode derivar de seu único fundamento, o evento Jesus confessado como Cristo. Isso significa que a unidade é real em cada uma das Igrejas, apesar de sua separação. Segundo Tillich (1984), a Igreja católica romana tem a pretensão de encarnar sozinha a unidade. O protestantismo, por definição, tomou mais consciência do caráter paradoxal da unidade da Igreja e considera a divisão das Igrejas inevitável, devido à ambiguidade da religião. Isso, porém, não é contraditório com a unidade, mas paradoxal. O Conselho mundial das Igrejas é um sinal concreto do desejo de reunir o que ele chama de Igrejas latentes. Contudo, nem o movimento ecumênico nem nenhum outro movimento poderá superar a ambiguidade da unidade e da divisão histórica das Igrejas. Pessimismo ou realismo? Seja como for, ele afirma que, no seio dessa realidade paradoxal, há um dinamismo profético sob o impulso do Espírito que suscita reformas constantes nas Igrejas (TILLICH, 1984).

O terceiro atributo é a universalidade: as Igrejas são universais, em razão de seu fundamento - o Novo Ser efetivo -, mas também histórica e culturalmente situadas. Tillich (1984, p. 515) busca substituir católico por universal porque, depois da Reforma, o primeiro termo ficou associado às Igrejas romana, grega ortodoxa e anglicana. Apesar dessa mudança de termos, a questão permanece: uma Igreja pode pretender a catolicidade sem deixar de ser uma Igreja particular?

Tillich (1984, p. 515-516) responde que pertence à própria natureza eclesial atualizar e tornar concreta a $\mathrm{CE}$, porque cada Igreja é universal de maneira extensiva e intensiva. A universalidade intensiva reside em seu desejo e em seu poder de participação em tudo o que é criado, em todas as dimensões da vida, porque nada do que é criado está excluído da vida das Igrejas e de seus membros. Tal é a significação da complexio oppositorum, princípio que postula, com razão, a Igreja romana (TILLICH, 1984, p. 515). Ora, esse princípio de universalidade intensiva não é sem riscos, pois ele inscreve elementos ambíguos na vida eclesial. Foi por essa razão que o protestantismo substituiu a abundância do complexio oppositorum pela pobreza do vazio sagrado, seguindo, nesse ponto, o judaísmo e o islamismo. Mas, segundo nosso autor (TILLICH, 1991), isso não significa que o protestantismo rejeitou o princípio de universalidade, inclusive porque existe também universalidade no vazio. Também é verdade que essa atitude protestante contribuiu para o aumento da secularização e para a redução da função da Igreja à vida privada, provocando uma perda de espaço de participação na vida em sua globalidade. Apesar de sua pobreza, as Igrejas permanecem essencialmente universais. $\mathrm{O}$ mesmo se dá quanto à sua universalidade extensiva: se tudo o que é criado diz respeito à Igreja, 
sua mensagem é dirigida a todos. Essa extensão do conceito é uma consequência direta da aceitação de Jesus como aquele que trouxe o Novo Ser. Na linha do apóstolo Paulo, a teologia deve insistir na universalidade das Igrejas frente aos problemas nacionais, raciais e culturais (TILLICH, 1991, v. 4, p. 187-189).

Finalmente, universalidade, unidade e santidade nunca são realidades efetivas na vida concreta das Igrejas: sua universalidade está presente em suas particularidades, a unidade se realiza no seio de separações e conflitos, e a santidade é testemunhada no meio de suas distorções. Contudo, essa realidade paradoxal da vida das Igrejas as torna dinâmicas e exprime-se como luta incessante contra toda ambiguidade.

\subsection{A vida das Igrejas e a ambiguidade da religião}

A CE participa da vida-sem-ambiguidades enquanto constitui uma comunidade de fé e de amor. Mas, por causa da finitude humana, essa participação fica fragmentária. As ambiguidades não são, portanto, eliminadas, mas, em princípio, podem ser superadas. A locução em princípio, para Tillich, não significa in abstracto: designa o começo, como denotam a palavra latina principium e a grega archè. Nesse sentido, a Presença Espiritual, o Novo Ser e a Comunidade Espiritual são princípios (archai), isto é, suscitam o dinamismo de um novo começo (TILLICH, 1964, p. 172-173). A ambiguidade da religião e sua força autodestrutiva estão sob certo controle na vida das Igrejas, graças à presença do Espírito, porque, onde o Espírito está presente, ali também as ambiguidades da religião são identificadas e rejeitadas, embora nunca definitivamente abolidas (TILLICH, 1991, v. 4, p. 191).

As Igrejas são comunidades de fé e de amor. $\mathrm{O}$ amor no campo religioso manifesta-se em um contexto de ambiguidade e de separação. A Igreja como comunidade de amor pressupõe que cada fiel mantenha com os outros uma relação de encontro pessoal e de proximidade (no sentido de próximo do NT), de aceitação mútua apesar de sua realidade sociológica, marcada por separações políticas, sociais, econômicas, intelectuais, nacionais, como também pessoais, ligadas aos gostos, às simpatias e às antipatias. Existe, porém, em certas Igrejas a ideia de uma comunidade de amor como renúncia a toda diferença. Ora, essa posição parece esquecer a distinção eclesial entre os aspectos teológico e sociológico (TILLICH, 1991, v. 4, p. 196).

Assim, a exigência de igualdade econômica, social e política não pode derivar diretamente do caráter comunitário da Igreja. Mas de tal exigência deve resultar que as formas de desigualdades, que tornam impossível a atualização da comunidade de amor e de fé, sejam combatidas e transformadas (TILLICH, 1991, v. 4, p. 196-1997). A palavra profética da Igreja deve fazer-se ouvir contra essas formas de desumanidade e de injustiça, sem esquecer de transformar suas próprias estruturas. Tudo isso diz 
respeito a "esse aspecto do amor (ágape) que se chama caridade, e que é tão necessário quanto ambíguo" (TILLICH, 1991, v. 4, p. 197, tradução nossa). A ambiguidade deriva do fato de que a caridade "pode substituir as obrigações para com os seres humanos por contribuições puramente materiais" (TILLICH, 1991, v. 4, p. 197, tradução nossa), assim como pode perpetuar as condições sociais que a tornam necessária, sem questionar uma ordem social injusta.

$\mathrm{O}$ amor verdadeiro engaja-se na criação das condições que restituem no outro a possibilidade de amar. Por sua vez, "todo ato de amor supõe juízo contra aquilo que nega o amor" (TILLICH, 1984, p. 522). A Igreja - comunidade de amor - exerce continuamente esse discernimento sobre sua própria realidade e sobre os que lhe são exteriores. Pelo fato de a Igreja exercer seu julgamento em nome da $\mathrm{CE}$, ela está exposta ao perigo de tornar-se mais radical, fanática, destruidora. Em contrapartida, o Espírito presente na Igreja julga esses próprios julgamentos e combate essas eventuais distorções (TILLICH, 1991, v. 4, p. 197).

Quanto ao aspecto mais ad intra, Tillich levanta o problema da disciplina como medium do julgamento da Igreja. Segundo ele, o melhor exemplo é a objeção do protestantismo à doutrina e à prática da excomunhão: "O princípio protestante impossibilita a excomunhão, porque nenhum grupo religioso tem o direito de interpor-se entre Deus e o ser humano, para unir o ser humano a Deus e para separá-lo de Deus" (TILLICH, 1991, v. 4, p. 198, tradução nossa). O aspecto ad extra refere-se à relação entre uma Igreja particular e as outras comunidades (TILLICH, 1991, v. 4, p. 199). O autor levanta questões em torno da pertença à CE de uma Igreja particular: como se deve considerar os outros quando eles adentram no domínio da Igreja?

A resposta do autor tem como ponto de partida a CE em estado latente, segundo três tipos de participação (TILLICH, 1991, v. 4, p. 199-200). O primeiro é o estilo clássico da conversão: quem deseja participar da comunidade de amor em uma Igreja particular torna-se plenamente membro dessa Igreja, aceitando seu credo e sua organização. O segundo, que chamaremos estilo fronteiriço de conversão: a pessoa fica em uma Igreja particular e ao mesmo tempo torna-se hóspede perfeitamente admitida em outra. $\mathrm{O}$ terceiro corresponde ao estilo latente do tipo de comunhão espiritual: a pessoa continua no estado latente da $\mathrm{CE}$, mas vivendo como judeu, muçulmano, humanista, místico, etc. A pessoa é acolhida na comunidade cristã como visitante e amiga.

Tillich endossa (1984), enfim, a recusa da teologia de identificar o cristianismo a uma religião: segundo o testemunho das Escrituras ${ }^{16}$, a vinda

\footnotetext{
${ }^{16}$ Sobre a relação com as Escrituras, interessante perceber a distinção entre a religião bíblica de Tillich e a hermenêutica bíblica de Ricoeur: cf. Souza (2011, p. 33-41).
} 
de Cristo não é o fundamento ou a fundação de uma nova religião, mas antes a transformação de um antigo status quo das religiões. Jesus não anunciou a vinda de uma nova religião, mas a proximidade do Reino de Deus. Jesus minimiza assim a importância das leis religiosas em nome do poder e da dinâmica do Reino de Deus, presente em Sua pessoa. Por conseguinte, a Igreja, mais que uma comunidade religiosa entre outras, é figura antecipadora de uma nova realidade: "tudo o que foi dito até aqui sobre as Igrejas e seus membros indica o sentido de uma superação da religião" (TILLICH, 1995, p. 212, tradução nossa). O processo de superação parte do princípio dos princípios: a verdadeira religião é aquela em que o próprio Deus se doa, e a falsa religião é aquela em que se procura a Deus em vão (TILLICH, 1990, p. 199-79). Não se trata, contudo, de um julgamento a priori da religião, mas de uma situação oferecida ao discernimento.

\subsection{A realização do ser humano como experiência de uma vida nova}

Para Tillich, entrar em uma Igreja significa passar do estado latente ao estado manifesto de participação na CE e entrar na dinâmica de luta contra as ambiguidades em vista de uma vida renovada. Ele chama essa passagem de "experiência do Novo Ser", que consiste na tomada de consciência de ser tomado pela PE (TILLICH, 1991, v. 4, p. 241), o que a grande tradição cristã exprimiu em três termos: regeneração, justificação e santificação.

Por regeneração, designa-se a experiência do Novo Ser, no sentido paulino de novo nascimento e nova criação. A experiência de um novo nascimento não significa, porém, que a pessoa é automaticamente renovada, mas que ela entra em uma nova dinâmica de vida (TILLICH, 1991, v. 4, p. 241-242). É por isso que os teólogos da Reforma e seus sucessores preferiram começar suas análises pondo em evidência o caráter paradoxal da experiência, primeiro partindo da justificação para, em seguida, falar da regeneração. Eles queriam evitar que o novo nascimento fosse interpretado como a causa da aceitação do ser humano por Deus. Ora, só Deus é a origem incondicional da fé; do contrário, a fé se degrada em crença (TILLICH, 1991, v. 4, p. 242).

Efetivamente, a justificação tornou-se central para a Reforma. Para Tillich (1991, p. 243), a justificação, mais que uma doutrina, é um princípio fundamental, segundo o qual o protestantismo se mantém ou naufraga: o princípio protestante significa que, em nossa relação com Deus, só Deus age; nenhuma aspiração humana, seja religiosa, moral ou piedosa, pode nos unir a Deus.

A terceira experiência é a santificação como processo de uma vida sob a influência do Espírito. Esse processo repousa na experiência de regeneração qualificada, de justificação, que desabrocha como santificação (TILLICH, 
1991, v. 4, p. 248). Originalmente, justificação e santificação referiam-se à mesma realidade, a saber: a superação das ambiguidades da vida pessoal. Contudo, o termo justificação recebeu progressivamente o significado de aceitação paradoxal do que é inaceitável. Por sua vez, a santificação ganhou o sentido de transformação efetiva ou, mais precisamente, o processo da vida sob a influência do Espírito Santo (TILLICH, 1991, v. 4, p. 249).

Apesar das diferenças de interpretação do processo da santificação, segundo as diversas confissões cristãs, Tillich (1991, p. 249-257) indica quatro critérios para uma "nova doutrina da vida segundo a Presença Espiritual": primeiro, o critério de uma consciência crescente da presença das ambiguidades e, ao mesmo tempo, consciência de um dinamismo de vida; segundo, o de uma liberdade crescente ou a experiência de libertação frente às formas coercitivas da lei e frente ao seu próprio conteúdo; terceiro, o critério da relacionalidade crescente como capacidade de entrar em relação, superando o fechar-se sobre si mesmo; e, finalmente, o último, o princípio da autotranscedência. Decerto, o fim da maturidade sob a ação do Espírito Santo compreende a consciência, a liberdade e a relação com os outros, mas tudo isso implica um movimento de autotranscendência. Não poderia, portanto, haver santificação sem ato de autotranscendência orientado para o Último, isto é, à participação, fragmentária, mas real, na santidade de Deus, único verdadeiramente Santo.

A realização do ser humano para Tillich, portanto, não significa uma superação definitiva das ambiguidades, nem é um ideal etéreo, mas uma experiência vivida como regeneração (TILLICH, 1984, p. 553-555), justificação (TILLICH, 1984, p. 555-558) e santificação (TILLICH, 1984, p. 558-590). Tais experiências são fragmentárias, mas, nem por isso, menos reais e significativas: a despeito de toda finitude essencial e de toda alienação existencial, a fé é proposta ao ser humano como promessa de uma realização. Essa promessa, feita a Abraão, pai da fé, e experimentada fragmentariamente pelo ser humano, foi realizada plenamente por e em Jesus, o Cristo. Ele, porém, não estava sozinho: o Espírito estava com Ele. E Jesus não deixou órfãos (Jo 14,18) os seus discípulos, nem os de ontem nem os de hoje: "Porque o Espírito permanecerá com os discípulos, mesmo partindo, Jesus não os deixa órfãos" (MALZONI, 2018, p. 246).

\section{À guisa de conclusão: "só o Espírito pode discernir o Espírito"}

No final desse percurso com Paul Tillich, o que se pode concluir? Como esse teólogo do século passado pode ajudar a compreender a situação contextual brasileira do crer? 
Sem dúvida, a situação brasileira é caracterizada por uma grande efervescência, enraizada em uma matriz religiosa popular, plena de ambiguidades, mas também de dinamismo (RUBENS, 2008): a revalorização da religiosidade e sabedoria populares pelo Papa Francisco reclama uma nova abordagem teológica da fé simples e elementar (SCANONNE, 2019, p. 65-180). O desafio, porém, é, por um lado, não descartar, a priori, essas experiências que se manifestam como desejo real da busca de Deus e da realização humana, apesar das ambiguidades da vida; por outro lado, não renunciar à busca de critérios teológicos que considerem a experiência humana da fé, em sua tríplice estrutura e integralidade: a dimensão subjetiva (verificação da autenticidade das experiências), a intersubjetiva (experiência comunitária e laços sociais) e a objetiva da verdade (consenso e/ou definições $)^{17}$.

Pensar com Tillich ${ }^{18}$ significa recusar uma oposição simples entre religião e fé para reconsiderar uma relação dialética entre as duas: o cristianismo é uma religião da superação constante da religião, como postula nosso autor. E a ambiguidade, de fato, não diz respeito somente ao fenômeno religioso, mas à experiência humana como tal. Portanto, se considerarmos a ambiguidade como constitutiva da experiência humana, em vez de eliminá-la, será preciso exercitar um verdadeiro discernimento teológico e pastoral.

Tal discernimento teológico, no entanto, não se justifica unicamente como urgência pastoral de nosso contexto, mas como exigência profunda do ato de crer e da tarefa teológica constante de "dar razões de nossa esperança" (1Pd 3,15). Teologia como discernimento supõe uma pneumatologia, pois "só o Espírito discerne o Espírito" (TILLICH, 1991, v. 4, p. 264, tradução nossa); mas, graças à sua Presença no mundo, podemos identificar seus traços e elaborar critérios de discernimento que considerem tanto a imprevisibilidade divina - "O Espírito sopra onde quer" - como a discrição da sua Presença - "tu ouves a sua voz, mas não sabes de onde vem nem para onde vai" (Jo 3,8). Assim o Espírito de Deus age no espírito humano sem ferir a sua liberdade, mas fazendo-o crer $^{19}$.

\footnotetext{
${ }^{17}$ Desenvolvimento mais detalhada na obra de Rubens (2004, p. 426s).

${ }^{18}$ Mais que uma expressão, Pensar com Tillich significa, para mim, uma maneira de fazer uma interlocução privilegiada (não simples aplicação) com um autor que, embora em um contexto totalmente diferente, permite uma inteligência da fé em nossos dias (RUBENS, 2004, p. 135-322).

${ }^{19}$ Ver, sobre o Espírito, a belíssima reflexão de José Tolentino Mendonça, intitulada O imprevisível como tópico da visão de Deus (MENDONÇA, 2015, p. 91-99).
} 


\section{Referências}

ABREU, F. H. Religião como sistema de autointerpretação simbólica: os fundamentos da Teoria dos Símbolos de Paul Tillich. Correlatio, São Paulo, v. 18, n. 1, p. 1-36, jun. 2019.

ADÃO, F. S. La vie comme nourriture. Pour un discernement eucharistique de l'humain fragmenté. 2019. 371 p. Tese (Doutorado em Teologia) - Facultés Jésuites de Paris, Centre Sèvres, Paris, 2019.

CONCÍLIO VATICANO II. Gaudium et spes: Constituição Pastoral do Concílio Vaticano II sobre a Igreja no mundo de hoje. 16.ed. São Paulo: Paulinas, 2009.

CRUZ, E. R. A dupla face: Paul Tillich e a ciência moderna, ambivalência e salvação. São Paulo: Loyola, 2008.

EMÍLIO, G. E. Ser-em-si e símbolo: a forma e a dinâmica da Teologia Sistemática de Paul Tillich. Correlatio, São Paulo, v. 9, n. 17, p. 154-177, jun. 2010.

GEFFRÉ, C. Révélation. Écriture et tradition dans la Dogmatique de 1925. In: RICHARD, J.; GOUNELLE, A.; SCHARLEMANN, R. P. (Ed.) Études sur la Dogmatique (1925) de Paul Tillich. Paris: Cerf; Québec: PUL, 1999. p. 201-214.

GEFFRÉ, C. De Babel à Pentecôte. Essais de Théologie interreligieuse. Paris: Cerf, 2010.

GOUNELLE. G. Paul Tillich. Une foi réfléchie. Lyon: Éd. Olivétan, 2013. p. 27.

GROSS, E. O conceito de fé em Paul Tillich. Correlatio, São Paulo, v. 12, n. 23, p. 7-26, jun. 2013a.

GROSS, E. O conceito de religião em Paul Tillich e a ciência da religião. Correlatio, São Paulo, v. 12, n. 24, p. 59-76, dez. 2013 b.

HIGUET, E. A. Atualidade da teologia da cultura de Paul Tillich. Correlatio, São Paulo, v. 18, n. 2, p. 11-25, jul. / dez. 2019.

LOYOLA, I. Exercícios Espirituais. São Paulo: Loyola, 2000. p. 92-93.

MALZONI, C.V. Evangelho segundo João. São Paulo: Paulinas, 2018.

MENDONÇA, J. T. Nenhum caminho será longo: para uma teologia da amizade. São Paulo: Paulinas, 2013.

MENDONÇA, J. T. A Leitura Infinita: a Bíblia e a sua interpretação. São Paulo: Paulinas; Recife: Unicap, 2015.

RIBEIRO, C. O.; ABIJAUDI, A. Y. G. As religiões diante da preocupação última da vida: uma reflexão a partir do pensamento de Paul Tillich. Estudos de Religião, São Paulo, v. 31, n. 3, p. 349-375, set. / dez. 2017.

RUBENS, P. Discerner la foi dans des contextes religieux ambigus. Enjeux d'une théologie du croire. Paris: Cerf, 2004.

RUBENS, P. O Rosto Plural da Fé: da ambiguidade religiosa ao discernimento do crer. São Paulo: Loyola, 2008.

RUBENS, P. La foi aux prises avec l'ambiguïté postmoderne: Penser avec Paul Tillich la méthode théologique. In: DANZ, C. et al. (Ed.). International Yearbook for Tillich Research. Berlin; Boston: De Gruyter, 2016. p. 1-22. 
SCANONNE, J. C. A teologia do povo: raízes teológicas do Papa Francisco. São Paulo: Paulinas, 2019.

SOUZA, V. C. A religião bíblica de Paul Tillich e a hermenêutica bíblica de Paul Ricoeur. Correlatio, São Paulo, v. 10, n. 19, p. 33-41, jun. 2011.

THEOBALD, C. Le christianisme comme style. Une manière de faire de la théologie en postmodernité. Paris: Cerf, 2007. v. 1.

THEOBALD, C. Vaticano II: do "concílio pastoral" à "pastoralidade conciliar". Recife, 12 out. 2012. Disponível em: <http://unicap-cursodeteologia.blogspot.com. br/2012/10/normal-0-21-false-false-false-pt-br-x_12.html>. Acesso em: 27 mar. 2020.

TILLICH, P. Systematic Theology. Chicago: The University of Chicago Press, 1963. v. 3.

TILLICH, P. Amour, pouvoir et justice. Paris: PUF, 1964.

TILLICH, P. Dynamique de la foi. Paris; Tournai: Casterman, 1968.

TILLICH, P. Théologie systèmatique. Paris: Planète, 1970. v. 2.

TILLICH, P. Théologie systèmatique. Lausanne: éd. L'Âge d'Homme, 1980. v. 3.

TILLICH, P. Teologia Sistemática. São Paulo: Paulinas; São Leopoldo: Sinodal, 1984.

TILLICH, P. La dimension religieuse de la culture. Paris: Cerf; Genève: Labor et Fides; Québec: PUL, 1990.

TILLICH, P. Théologie systèmatique. La vie et l'Esprit. Genève: Labor et Fides, 1991. v. 4.

TILLICH, P. Substance catholique et principe protestant. Paris: Cerf; Genève: Labor et Fides; Québec: PUL, 1995.

TILLICH, P. Documents biographiques. Paris: Cerf; Genève: Labor et Fides; Québec: PUL, 2002.

TILLICH, P. Le christianisme et la rencontre des religions. Genève: Labor et Fides, 2015.

Artigo submetido em 04.04.2020 e aprovado em 03.08.2020.

Pedro Rubens Ferreira Oliveira SJ, é Doutor em Teologia pelas Facultés Jésuites de Paris (2002), professor da FAJE (2002-2005) e professor da Unicap, desde 2006, onde é pesquisador do Programa de Pós-graduação em Teologia. orcid.org/0000-0002-2736-5523. E-mail: pedro. rubens@unicap.br

Endereço: Rua do Príncipe, 526- Boa Vista 50050-000 Recife - PE 